\title{
37. ANTARCTIC SILICOFLAGELLATES FROM THE SOUTHEAST PACIFIC, DEEP SEA DRILLING PROJECT LEG 35
}

\author{
Bilal U. Haq and Anne Riley, Woods Hole Oceanographic Institution, Woods Hole, Massachusetts
}

\section{INTRODUCTION}

During February/March 1974, four sites were drilled during the Deep Sea Drilling Project Leg 35 in the Southeast Pacific Basin (two on the Bellingshausen Abyssal Plain and two on the Antarctic continental rise) (Figure 1). This was the third cruise of D/V Glomar Challenger in the Antarctic waters, the earlier cruises being Legs 28 and 29. Sediment recovery was poor at all sites and siliceous microfossils were recovered from relatively few diatomaceous layers in the cores. A summary of site locations, coring data, and recovery of silicoflagellates is given in Table 1 .

\section{SILICOFLAGELLATES OF LEG 35}

Poorly to moderately well preserved silicoflagellates were recovered at all sites, but specimens were rare to very rare, and only occurred at intermittent levels of the cored intervals. One silicoflagellate slide was prepared from each sample studied for radiolarians (Weaver, this volume). A total of 219 samples were examined from the four sites. Only 65 of these contained silicoflagellates, which are middle Miocene to Pliocene in age. All specimens were counted. The species distribution is presented in Tables 2-4.

\section{Biostratigraphic Considerations}

Silicoflagellates have evolved at a slower pace relative to other microfossil groups, and thus silicoflagellate zones are inherently of longer durations. A number of zonal schemes have been suggested in recent years for the Mio-Pliocene interval. Bukry (1973, 1975), Ling (1973), and Perch-Nielsen (1975) have all proposed zonations for the Mio-Pliocene interval of nontropical areas based on the material cored during DSDP Legs 16, 19 , and 29 . However, due to the very high latitudinal position of the area studied here (south of $60^{\circ} \mathrm{S}$ ), these zonations could not be used effectively. The zonal scheme suggested by Ciesielski (1975) based on DSDP Leg 28 material (also in latitudes south of $60^{\circ} \mathrm{S}$ ), and ELTANIN piston-cores was found to be more useful, and we have tried to follow this scheme as much as possible. However, due to lack of continuous coring during Leg 35, general paucity of silicoflagellates and problems of poor preservation, no detailed biostratigraphic work could be accomplished on the present material.

The zonal concepts we used for the Mio-Pliocene interval and based on Ciesielski (1975) are summarized below:

1) Corbisema triacantha Zone (late early Miocene) Interval from the last occurrence of Naviculopsis navicula and/or $N$. regularis to the last consistent occurrence of Corbisema triacantha.

\section{2) Distephanus longispinus Zone (early middle} Miocene)

Interval from last consistent occurrence of Corbisema triacantha to first appearance of Dictyocha mutabilis.

3) Dictyocha mutabilis Zone (middle Miocene)

Range zone of $D$. mutabilis.

4) Paradictyocha circulus Zone (late Miocene)

Interval from first to last consistent occurrence of $P$. circulus.

5) Mesocena diodon Zone (late Miocene-early Pliocene)

Interval from last consistent occurrence of Paradictyocha circulus to first common occurrence of Dictyocha pseudofibula.

6) Dictyocha pseudofibula Zone (mid early Pliocene) Interval from first common occurrence of $D$. pseudofibula to the first common occurrence of $D$. aspera var. pygmaea and $D$. fibula var. pumila.

7) Dictyocha aspera Zone (late early Pliocene) Interval from first to last common occurrences of $D$. aspera var. pygmaea and D. fibula var. pumila.

8) Distephanus boliviensis Zone (middle Pliocene) Interval from last common occurrences of Dictyocha aspera var. pygmaea and D. fibula var. pumila to the last common occurrence of Distephanus boliviensis.

Not all of these zones were found in the material from Leg 35 and in some cases the diagnostic species were present but in very rare numbers. Silicoflagellates of each site are described below.

\section{Site 322}

Twenty species of silicoflagellates were observed, mostly in few to rare numbers, in Core 1, Section 1 through Core 4, Section 2. Below Core 2, Section 2 only rare fragments of the species more common in upper levels were seen. All sections between 4-2 and 10, CC were barren of silicoflagellates. The distribution of various species at this site is presented in Table 2.

Distephanus boliviensis is rare in the core-catcher of Core 1 and above; however, the "short-spined" variety of D. speculum is common and there were also rare occurrences of the "long-spined" variety. Based on this evidence alone, it is difficult to assign a biostratigraphic zone to this interval. On the basis of the whole assemblage, however, it is assigned an age of late Miocene to early Pliocene.

\section{Site 323}

Out of the 18 cores recovered from Site 323, only the upper 9 yielded silicoflagellates. Silicoflagellates were very rare in Cores 9, CC through 7-1. Similarly, other intermittent layers (6-1 to 5-1, 3-1, and 1-3 to 1-1) either contained very rare silicoflagellates or were completely barren. Twenty-one species were observed in the 32 


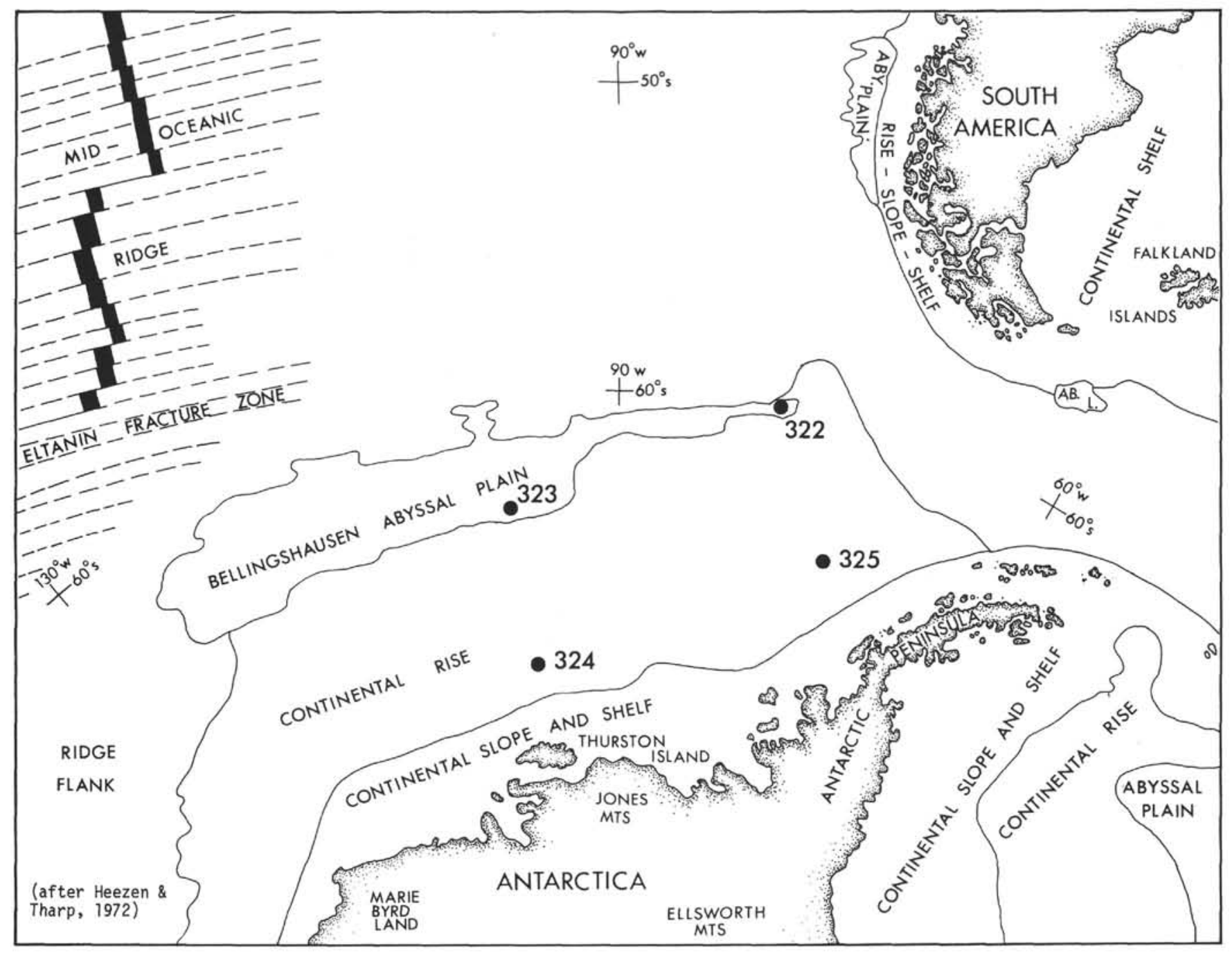

Figure 1. Locations of DSDP Leg 35 sites.

TABLE 1

Core Locations and Recovery Data for DSDP Leg 35

\begin{tabular}{|c|c|c|c|c|c|c|c|c|}
\hline Site & $\begin{array}{l}\text { Latitude, } \\
\text { Longitude }\end{array}$ & $\begin{array}{l}\text { Water } \\
\text { Depth } \\
\text { (m) }\end{array}$ & $\begin{array}{l}\text { Penetration } \\
\text { (m) }\end{array}$ & $\begin{array}{l}\text { No. of } \\
\text { Cores }\end{array}$ & $\begin{array}{l}\text { Meters } \\
\text { Cored }\end{array}$ & $\begin{array}{c}\text { Meters } \\
\text { Recovered }\end{array}$ & $\begin{array}{c}\text { Oldest } \\
\text { Sediments }\end{array}$ & $\begin{array}{c}\text { Silicoflagellates } \\
\text { Recovered } \\
\text { (Core-Section) }\end{array}$ \\
\hline 322 & $\begin{array}{l}60^{\circ} 01.45^{\prime} \mathrm{S}, \\
79^{\circ} 25.49^{\prime} \mathrm{W}\end{array}$ & 5026 & 544 & 14 & 125.5 & 34.2 & Miocene & $4-2$ to $1-1$ \\
\hline 323 & $\begin{array}{l}63^{\circ} 40.84^{\prime} \mathrm{S}, \\
97^{\circ} 59.69^{\prime} \mathrm{W}\end{array}$ & 4993 & 731 & 21 & 199.5 & 76.7 & $\begin{array}{l}\text { Upper } \\
\text { Cretaceous }\end{array}$ & $9, \mathrm{CC}$ to $1-1$ \\
\hline 324 & $\begin{array}{l}69^{\circ} 03.21^{\prime} \mathrm{S}, \\
98^{\circ} 47.20^{\prime} \mathrm{W}\end{array}$ & 4449 & 218 & 10 & 95.0 & 48.1 & Pliocene & $1-6$ to $1-1$ \\
\hline 325 & $\begin{array}{l}65^{\circ} 02.79^{\prime} \mathrm{S}, \\
73^{\circ} 40.40^{\prime} \mathrm{W}\end{array}$ & 3745 & 718 & 10 & 95.0 & 34.4 & $\begin{array}{c}\text { Upper } \\
\text { Oligocene/ } \\
\text { lower } \\
\text { Miocene }\end{array}$ & $3, \mathrm{CC}$ to $2-1$ \\
\hline
\end{tabular}

samples that yielded silicoflagellates. The distribution of various species is shown in Table 3 .

Most zone-diagnostic species in this material occur only in rare to very rare numbers and thus the zonal scheme, which is mainly based on consistent or common occurrence of taxa, can be used only tentatively at best.
The interval from $9, \mathrm{CC}$ to $6, \mathrm{CC}$ is tentatively placed within the late early Miocene Corbisema triacantha Zone due to the presence of this species in Sample 6, CC. The base of this zone, which is defined by the last occurrence of Naviculopsis navicula, is not observed in the present material and thus all samples up to $9, \mathrm{CC}$ are included in 
TABLE 2

Distribution of Silicoflagellates at Site 322, Late Miocene/Early Pliocene

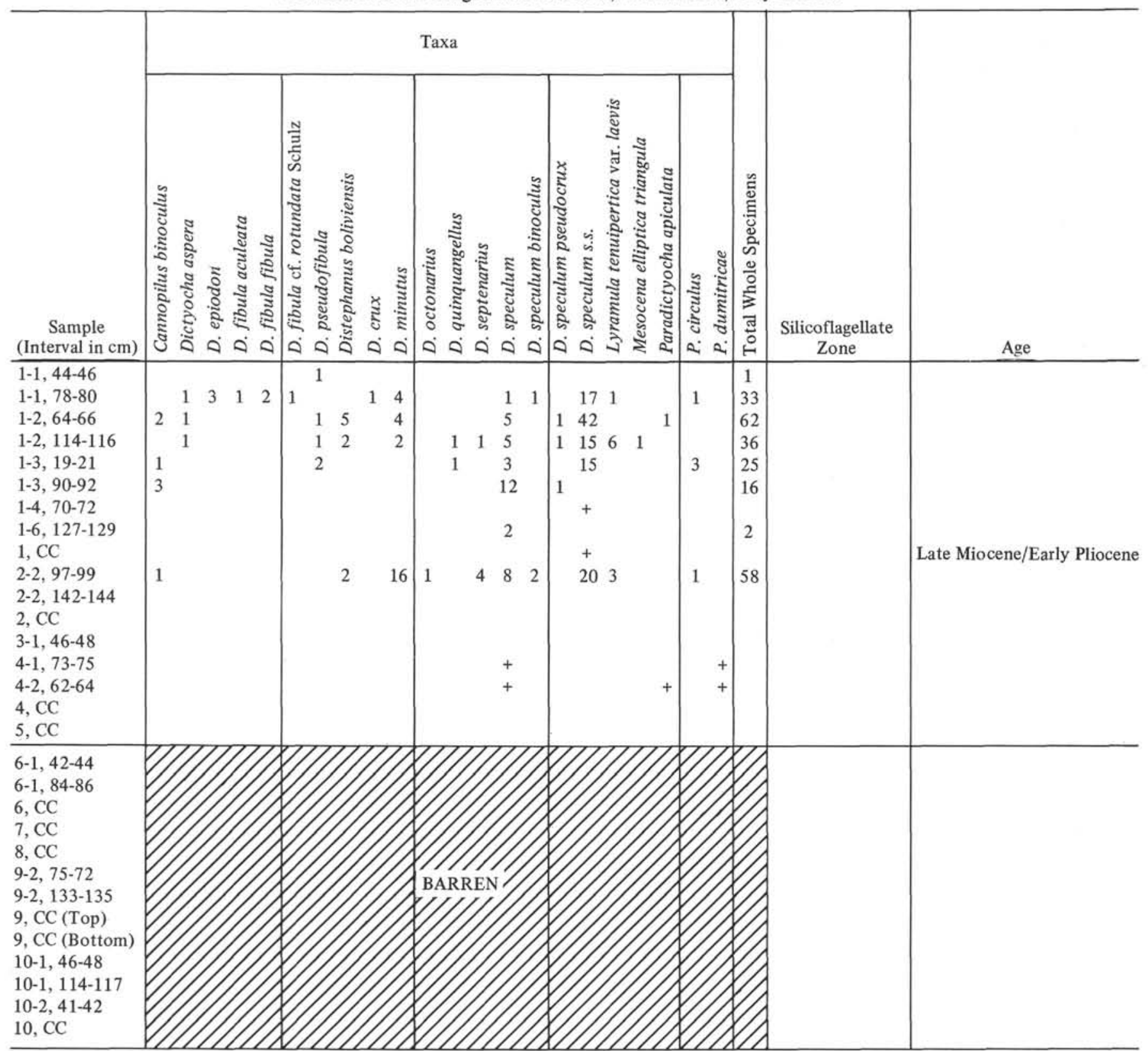

Note: $+=$ Fragments only.

this zone. Dictyocha mutabilis was observed in Sample 4, CC only and Paradictyocha circulus was observed in 3, $\mathrm{CC}$ through $3-2,80-82 \mathrm{~cm}$. Based on these taxa, Sample $4, \mathrm{CC}$ is assigned to the middle Miocene Dictyocha mutabilis Zone and 3, CC through 3-2, 80-82 cm to the late Miocene Paradictyocha circulus Zone. A few specimens of Dictyocha pseudofibula were found in 2, $\mathrm{CC}$, and thus it is assigned to that zone. All samples above $2, \mathrm{CC}$ through $1-4,16-18 \mathrm{~cm}$ are tentatively placed within the middle Pliocene Distephanus boliviensis Zone due to the presence of this species together with the "short-spined" variety of D. speculum.

The size of individuals within species varies with depth at this site. Cores 9 through 5 contain very small silicoflagellates; Cores 4 through 2 contain the same forms almost double in size. Most of Core 1 (1, CC to 13) resembles Cores 9 through 5 in size of individuals, but the upper sections (1-2 and 1-1) contain rare but larger forms once again.

\section{Site 324}

Silicoflagellates were found only in Core 1 at this site; all the other cores ( 2 through 9$)$ were barren. Twelve species were recognized and species distributions are noted on Table 4. The presence of Distephanus boliviensis together with the "short-spined" variety of $D$. speculum places this core within the mid-Pliocene $D$. boliviensis Zone. The silicoflagellates are small 
TABLE 3

Distribution of Silicoflagellates at Site 323, Early Miocene to Middle Pliocene

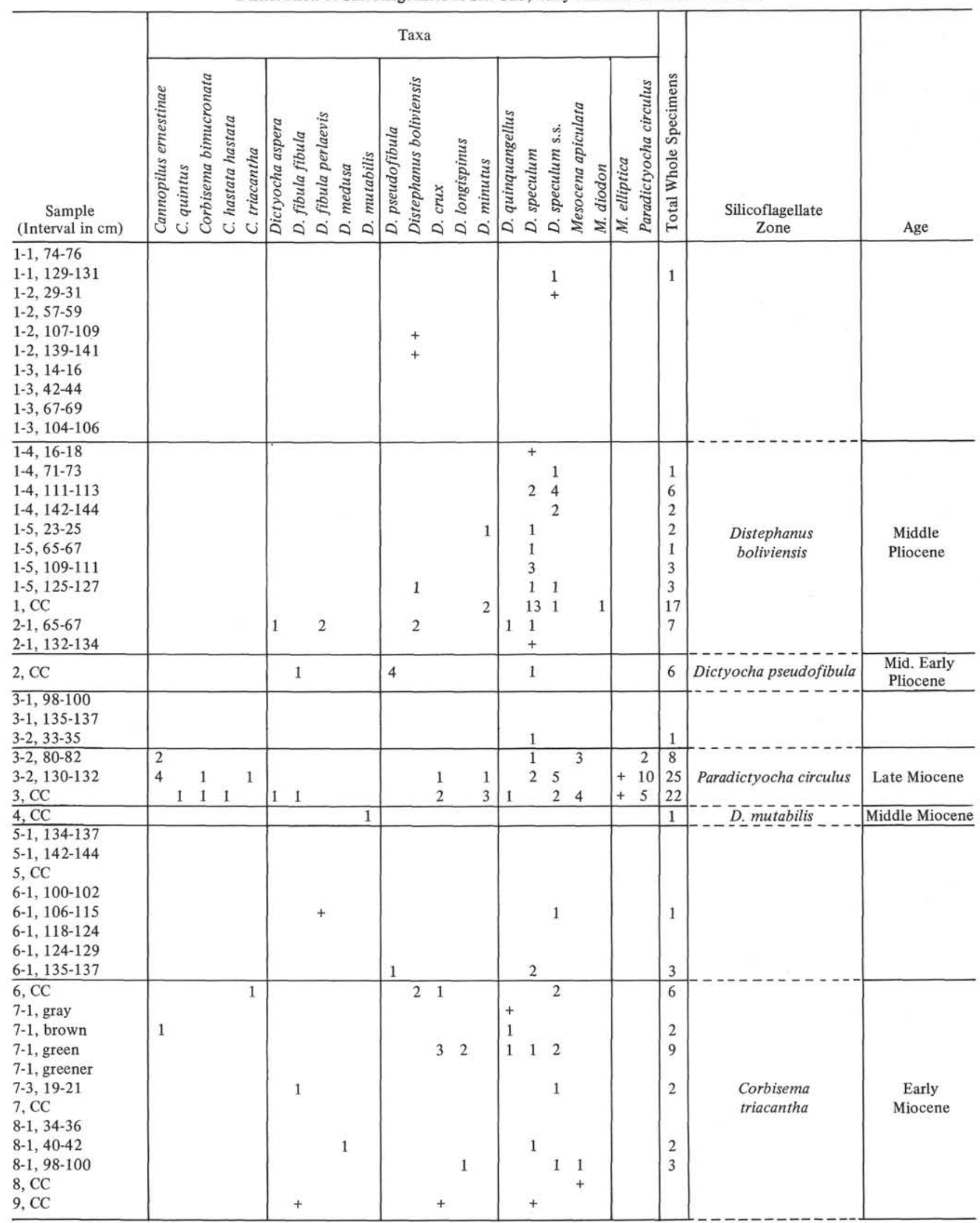


TABLE 3 - Continued

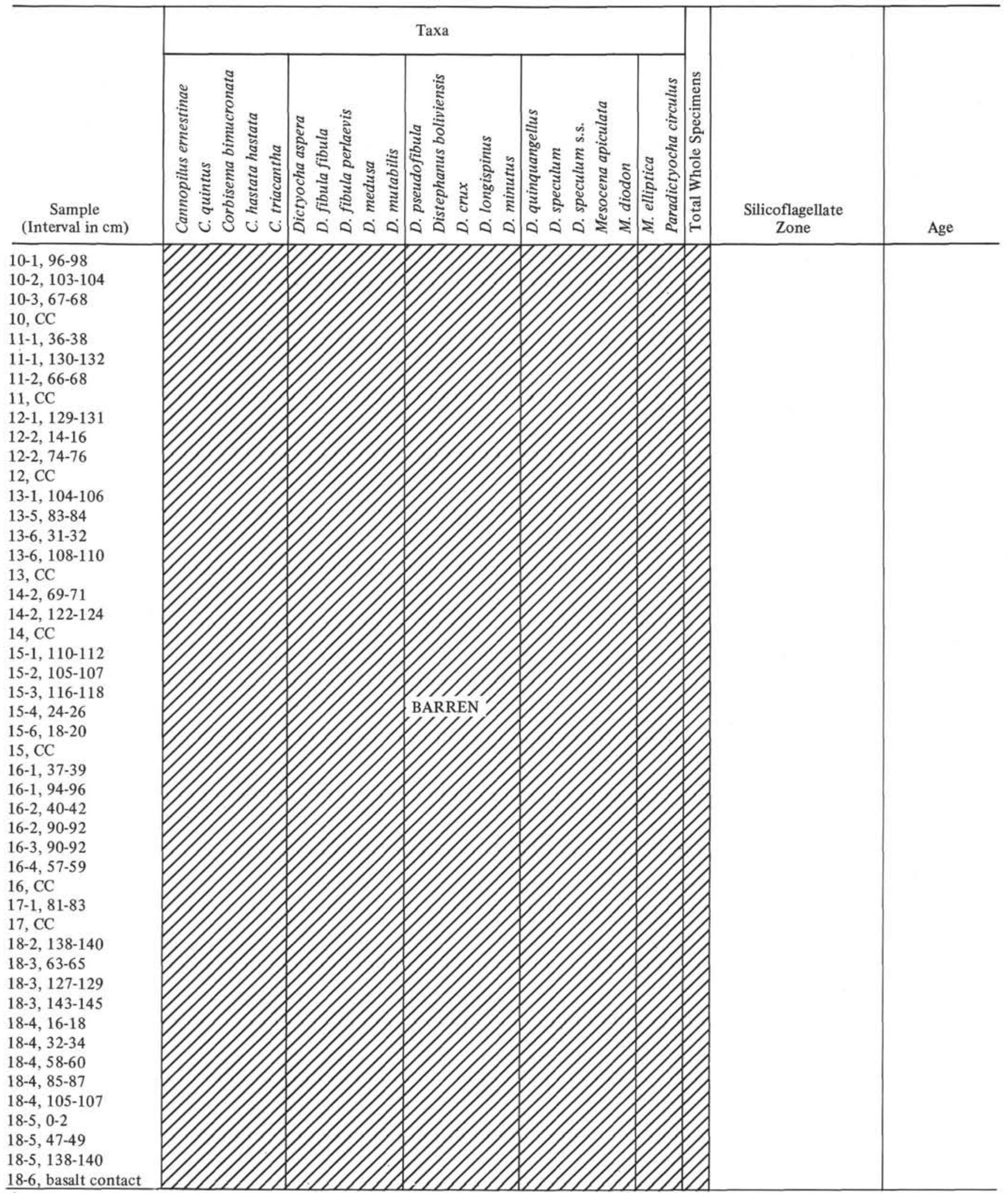

Note: $+=$ fragments only. 
TABLE 4

Distribution of Silicoflagellates at Site 324, Middle Pliocene

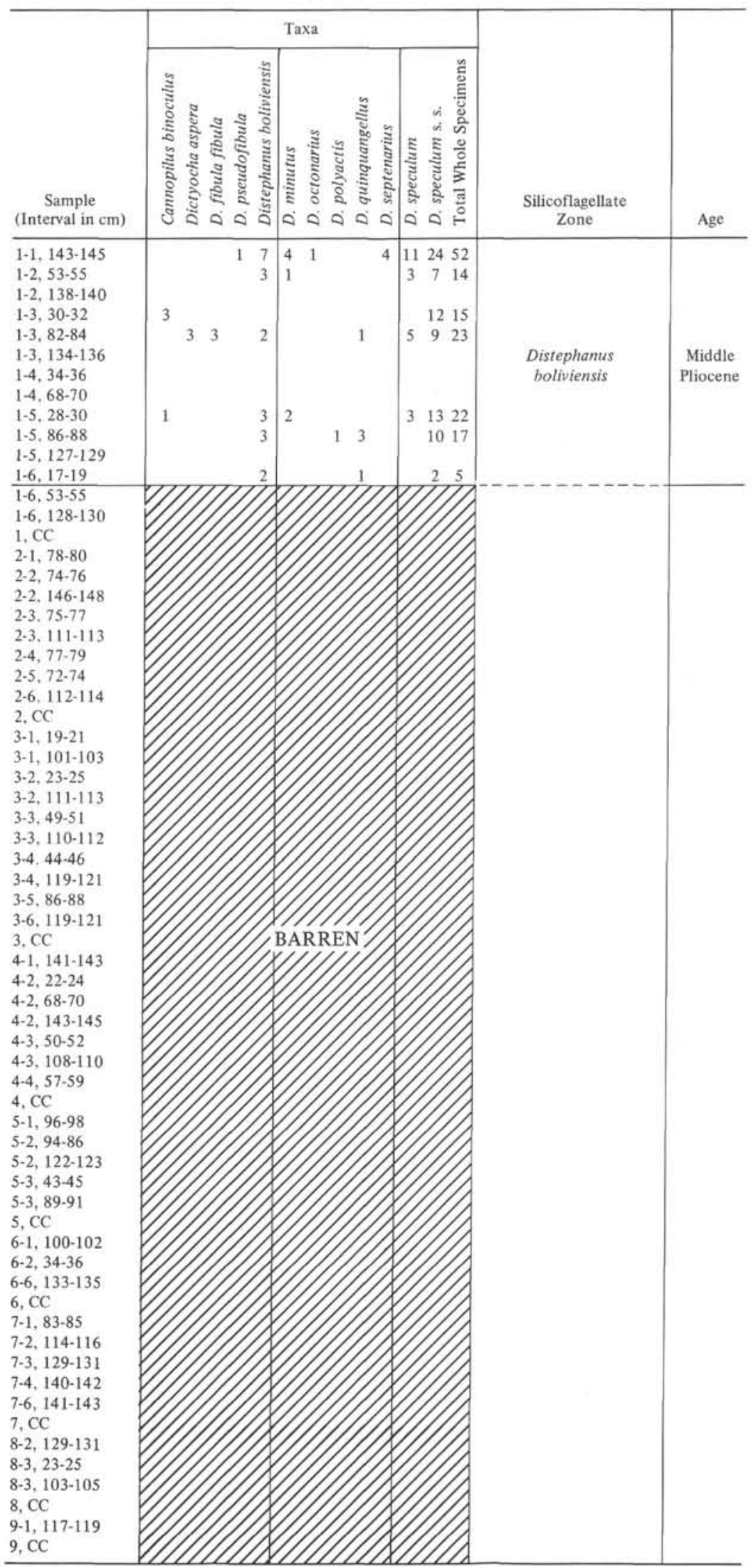


throughout this core, but they tend to be even smaller in the upper part of Core 1.

\section{Site 325}

At this site silicoflagellates were recovered only from Cores 2 and 3; Cores 1, and 5 through 9 are barren. Thirteen species from 14 samples are recognized; in some samples silicoflagellates are common (see Table 5). We place Cores 2 and 3 within the mid-Pliocene Distephanus boliviensis Zone due to the presence of $D$. speculum of both short- and long-spined varieties. In the lower two samples (Core 3, Section 4, 106-108 and 45-47 $\mathrm{cm}$ intervals) the average species size is large, but above this level it reduces considerably and in all samples in 32 through 2-1 only small forms were found.

\section{DISCUSSION}

Due to the poor sediment recovery and intermittent coring during Leg 35 and the general scarcity of silicoflagellates, we cannot attempt paleooceanographic and paleoclimatological interpretations based on our data. The only factor worth further consideration is the systematic changes in the size of individuals of a species at different levels of the cored sites.

At Site 323 the average specimen is small to intermediate in the middle Miocene, changing to predominantly large specimens in the late Miocene (Paradictyocha circulus and Dictyocha pseudofibula zones) and returning to forms of reduced size in the middle Pliocene Distephanus boliviensis Zone. In this zone at other sites (324 and 325) the average specimen size is also predominantly small diminishing in size in the upper parts of the zone. The reason for such size variations is unknown. However, during periods of smaller average sizes specimens are generally more numerous, and it can be speculated that either these periods represent times of enriched nutrient levels or even possibly higher temperatures. A higher nutrient level may lead to more rapid turnover and average smaller size but greater diversity. If the repeatability of such size variation could be demonstrated elsewhere and its constancy ascertained, this factor may eventually prove to be an important biostratigraphic and paleoecologic tool in the higher latitudes.

\section{TAXONOMIC NOTES}

In the next pages we briefly remark on our concepts of the taxa encountered. We have made extensive use of the annotated index of silicoflagellates by Loeblich et al. (1968) for the original descriptions of most of the taxa described before 1967 .

\section{Order SIPHONOTESTALES Lemmermann, 1901}

Genus CANNOPILUS Haeckel, 1887, emend. Bachmann, 1967

\section{Cannopilus binoculus (Ehrenberg) Lemmermann}

(Plate 1, Figures 10-12)

Dictyocha binoculus Ehrenberg, 1844, fide Loeblich et al., 1968, Geol. Soc. Am. Mem. 106, p. 83 , pl. 8 , fig. 8.

Cannopilus binoculus (Ehrenberg) Lemmermann, 1901, Bukry and Foster, 1973, Initial Reports of the Deep Sea Drilling Project, v. 16 , p. 825 , pl. 1, fig. 1, 2.

Remarks: This species has a large six- or seven-sided basal ring which is symmetric and has radial spines of equal length at each angle. It is characterized by a large apical ring symmetrically divided into two windows by a bar.

\section{Cannopilus ernestinae Bachmann}

(Plate 1, Figures 1-3)

Cannopilus ernestinae Bachmann, 1962, fide Loeblich et al., 1968, Geol. Soc. Am. Mem. 106, p. 64, pl. 1, fig. 6.

Remarks: One specimen, identified only in side view (see pl. 1, fig. 6 , in Loeblich et al., 1968) was observed at Site 323. This species commonly has a pentagonal basal body ring, and five relatively long, straight, perpendicular, lateral rods which rise from slightly to one side of midpoints between five radial spines. Basal accessory spines are absent. The lateral rods support an apical structure of five windows and one or more vertical, apical spines. The five lateral windows, though unequal in size, are generally four times larger than the apical windows. Hexagonal forms of this species occur rarely.

\section{Cannopilus major (Frenguelli)}

Dictyocha boliviensis Frenguelli var. major Frenguelli, 1951, fide Loeblich et al., 1968, Geol. Soc. Am. Mem. 106, p. 84, pl. 51, fig. 46.

Cannopilus major (Frenguelli), Bukry and Foster, 1973, Initial Reports of the Deep Sea Drilling Project, v. 16, p. 826, pl. 1, fig. 4-7.

Remarks: Typically large, Cannopilus major has a six- or sevensided basal ring and is distinguished by a large apical ring with three to seven windows of varying size.

\section{Cannopilus quintus Bukry and Foster}

Cannopilus quintus Bukry and Foster, 1973, Initial Reports of the Deep Sea Drilling Project, v. 16, p. 826, fig. 8, 9.

Remarks: Having an essentially symmetric pentagonal basal ring with distal spines at the apices, this species is characterized by a large apical ring divided into four asymmetric openings. A single specimen was found at Site 323 .

\section{Genus CORBISEMA Hanna, 1928}

\section{Corbisema bimucronata Deflandre} (Plate 1, Figure 4)

Corbisema bimucronata Deflandre, 1950, fide Loeblich et al., 1968, Geol. Soc. Am. Mem. 106, p. 75, pl. 5, fig. 8-11.

Corbisema bimucronata Deflandre, Ling, 1972, Am. Paleontol. Bull., v. 62 , no. 273 , p. 153 , pl. 24 , fig. 1 .

Remarks: The essentially triangular basal ring of this species is sharply truncated at each apex. Short spines occur at each end of the truncations. Basal accessory spines are short but generally present where three lateral rods join the basal ring at midpoints of the sides.

\section{Corbisema hastata hastata (Lemmermann)}

$$
\text { (Plate 1, Figure 6) }
$$

Dictyocha triacantha Ehrenberg var. hastata Lemmermann, 1901, fide Loeblich et al., 1968, Geol. Soc. Am. Mem. 106, p. 117, pl. 23, fig. 4,5 .

Corbisema hastata (Lemmermann), Bukry, 1973, Initial Reports of the Deep Sea Drilling Project, v. 21, p. 892, pl. 1, fig. 1.

Corbisema hastata hastata (Lemmermann), Bukry, 1975, Initial Reports of the Deep Sea Drilling Project, v. 29, p. 853, pl. 1, fig. 9.

Remarks: The isosceles form of this species has a distinctively indented basal side with radial spines at each end that are typically aligned with the long sides of the body ring.

\section{Corbisema triacantha (Ehrenberg)}

(Plate 1, Figure 5)

Dictyocha triacantha Ehrenberg, 1844, fide Loeblich et al., 1968, Geol. Soc. Am. Mem. 106, p. 116, pl. 23, fig. 1.

Corbisema triacantha (Ehrenberg), Hanna, 1931, Bukry and Foster, 1973, Initial Reports of the Deep Sea Drilling Project, v. 16, p. 826 , pl. 2, fig. 3 .

Corbisema triacantha (Ehrenberg), Mandra, 1968, Calif. Acad. Sci., Proc., ser. 4 , v. 36 , no. 9, p. 249 , fig. 28,31 .

Remarks: The basal ring of Corbisema triacantha is triangular with one spine radiating from each of the three apices. Mandra (1968) describes the length of each spine as approximately equal to the length of one side of the triangle. Three bars meeting at the center of the triangle divide the area into three equal parts. These lateral bars rise from the midpoint of each side of the basal ring. 
TABLE 5

Distribution of Silicoflagellates at Site 325

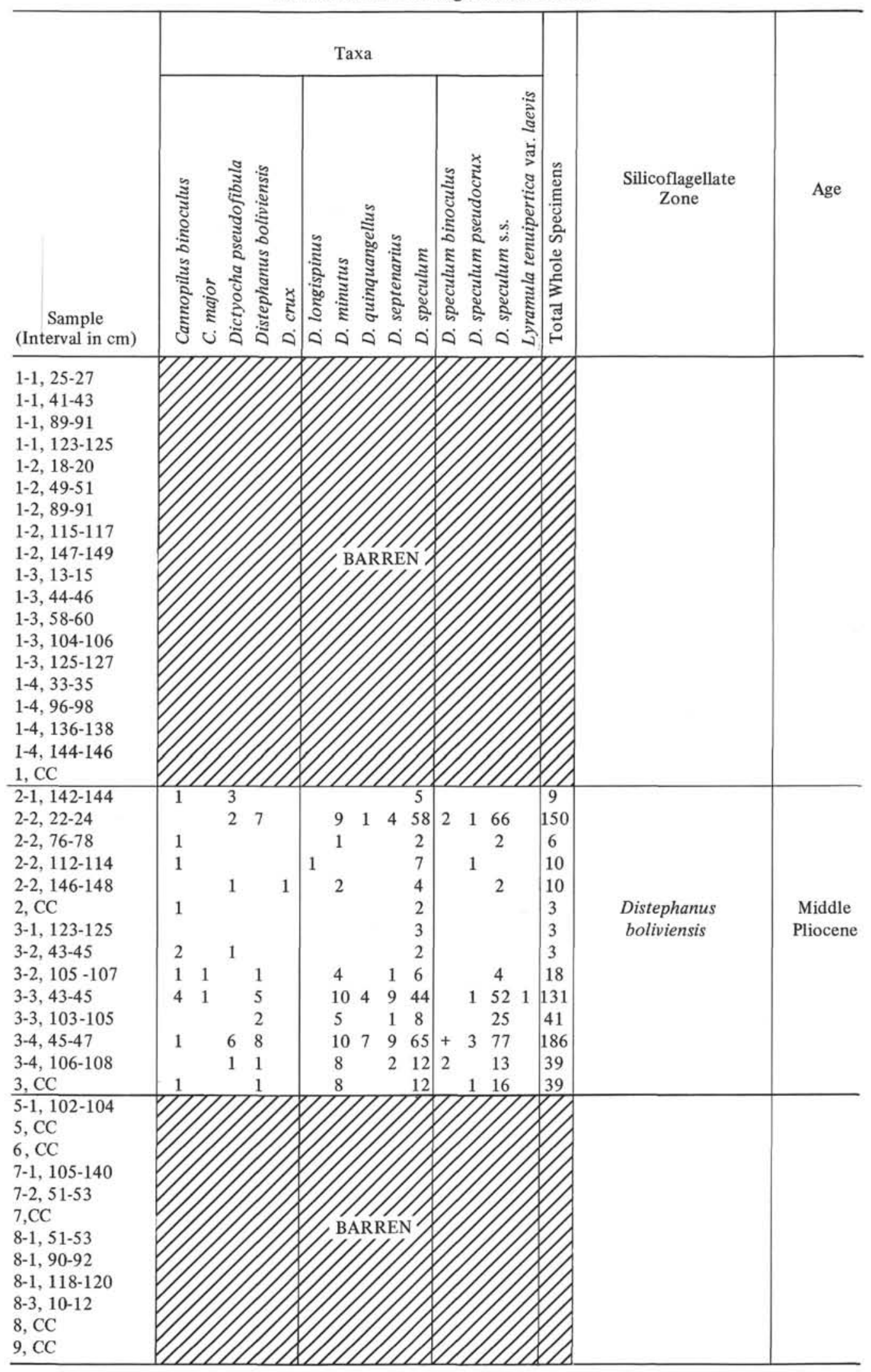

Note: $+=$ fragments only. 


\section{Genus DICTYOCHA Ehrenberg, 1837}

Dictyocha aspera (Lemmermann)

(Plate 1, Figures 7-9; Plate 2, Figure 6)

Dictyocha fibula var. aspera Lemmermann, 1901, fide Loeblich et al. 1968, Geol. Soc. Am. Mem. 106, p. 90-91, pl. 9, fig. 13, 14.

Dictyocha aspera (Lemmermann) Bukry and Foster, 1973, Initial Reports of the Deep Sea D illing Project, v. 16, p. 826, pl. 2, fig. 4-6.

Remarks: Dictyocha aspera characteristically has an apical bar aligned with the short axis of a curving, essentially quadrate, basal ring. Short radial spines delineate the axes and basal accessory spines may or may not be present.

\section{Dictyocha epiodon Ehrenberg}

(Plate 2, Figures 1-3)

Dictyocha epiodon Ehrenberg, 1844, fide Loeblich et al., 1968, Geol. Soc. Am. Mem. 106, p. 90, pl. 9, fig. 15-17.

Remarks: This species has an eight-sided basal ring with four major opposing spines and four alternate pikes. An apical bar, slightly offset to the long axis of the body ring, is supported by four lateral rods from the basal ring. Four proximally directed pikes generally occur on the body ring, one between each of the lateral struts.

\section{Dictyocha fibula var. aculeata Lemmermann}

Dictyocha fibula Ehrenberg var. aculeata Lemmermann, 1901, fide Loeblich et al., 1968, Geol. Soc. Am. Mem. 106, p. 90, pl. 9, fig. 1, 2.

Remarks: The basal ring of Dictyocha fibula var. aculeata is quadrate to octagonal and has four minor radial spines as well as four prominent ones. The apical bar is oriented parallel to the principal axis of the basal ring and characteristically has a vertical apical spine.

\section{Dictyocha fibula fibula Ehrenberg}

Dictyocha fibula Ehrenberg, 1839, fide Loeblich et al., 1968, Geol. Soc. Am. Mem. 106, p. 90, pl. 9, fig. 7-12.

Dictyocha fibula fibula Ehrenberg, Bukry, 1975, Initial Reports of the

Deep Sea Drilling Project, v. 29, p. 854, pl. 3, fig. 2, 3.

Remarks: The basal ring of this species may be rhomboid to elliptic in outline, but parallel to the longer axis is an apical bar. The axial alignment of the apical bar may be hard to determine in specimens with equilateral frames. For such forms, the longer pair of opposed radial spines can be used as an indication of major axis. Auxiliary distal pikes may or may not be present on the basal ring.

\section{Dictyocha fibula perlaevis (Frenguelli)} (Plate 2, Figure 4)

Dictyocha perlaevis Frenguelli, 1951, fide Loeblich et al., 1968, Geol. Soc. Am. Mem. 106, p. 109, pl. 51, fig. 7, 8.

Dictyocha fibula Ehrenberg, Bukry and Foster, 1973, Initial Reports of the Deep Sea Drilling Project, v. 16, p. 826, pl. 3, fig. 1.

Dictyocha fibula perlaevis (Frenguelli) Bukry, 1975, Initial Reports of the Deep Sea Drilling Project, v. 29 , p. 855 , pl. 3, fig. 5 .

Remarks: This species is similar to Dictyocha fibula fibula, but is larger and has shorter radial spines. In outline it is distinguished by a pronounced four-lobed basal ring. A simple apical bar, aligned with the long axis, is supported by four lateral rods which join the body ring at the base of each lobe.

\section{Dictyocha fibula ef. rotundata Schulz} (Plate 2, Figure 5)

Dictyocha fibula Ehrenberg var. pentagona Schulz forma rotundata Schulz, 1928, fide Loeblich et al., 1968, Geol. Soc. Am. Mem. 106, p. 96 , pl. 12, fig. 15 .

Dictyocha fibula var. rotundata (Schulz) Vozzhennikova, 1960, Akad. Nauk SSSR, Sibirskoe Otdel., Tr. Inst. geol. i geofiz., vyp. 1, Voprosy Stratigr. i Paleont. Zapadnoy Sibiri, p. 31, Table 6, p. 60 .

Remarks: One small specimen from Site 322 resembled Dictyocha fibula Ehrenberg var. pentagona Schulz forma rotundata Schulz as illustrated in Loeblich et al., 1968, p. 225, pl. 12, fig. 15. The basal ring is a prolate spheroid, flattened at the poles, having two radial spines midway along each curved side of the long axis. An apical bar aligned to the long axis is supported by four lateral struts forming an $\mathrm{H}$ shaped apical structure. Basal accessory spines are seen at the base of each strut which originate on the body ring at each end of the flattened polar areas.

\section{Dictyocha medusa Haeckel}

Dictyocha medusa Haeckel, 1887, fide Loeblich et al., 1968, Geol. Soc. Am. Mem. 106, p. 103, pl. 17, fig. 22, 23.

Remarks: Dictyocha medusa has no apical bar or apical ring. Its four-sided basal ring is conspicuously constricted where four opposed lateral rods rise from it. These four struts meet at a central point to form an X. The direct alignment of opposing struts across the central point distinguishes $D$. medusa from forms of Dictyocha aspera that have a vestigial apical bar.

\section{Dictyocha mutabilis Deflandre}

Dictyocha mutabilis Deflandre 1950, fide Loeblich et al., 1968, Geol. Soc. Am. Mem. 106, p. 105, pl. 18, fig. 7-14.

Remarks: The basal ring of Dictyocha mutabilis is an elongated ellipse with distinct radial spines at each end of the long axis. An apical bar aligned with the short axis is supported by four short lateral rods which form two small windows between each end of the apical bar and the midpoint of each long curve of the basal ring. These windows may swell the basal ring slightly, and each may have a minor radial spine central to its basal ring side. Two large windows result from the division of the basal ring by the apical structure. Basal accessory spines are rare.

\section{Dictyocha pseudofibula (Schulz)} (Plate 2, Figure 7)

Distephanus speculum (Ehrenberg) Haeckel forma pseudofibula Schulz, 1928, fide Loeblich et al., 1968, Geol. Soc. Am. Mem. 106, p. 123 , pl. 25 , fig. 12, 13.

Dictyocha pseudofibula (Schulz) Tsumura var. complexa Tsumura, 1963, fide Loeblich et al., 1968, Geol. Soc. Am. Mem. 106, p. 109, pl. 21 , fig. $5 \mathrm{a}, 5 \mathrm{~b}$.

Dictyocha pseudofibula (Schulz) Tsumura, 1963, Bukry and Foster,

1963, Initial Reports of the Deep Sea Drilling Project, v. 16, p. 827 , pl. 3 , fig. 2,11 .

Remarks: This species has a hexagonal basal ring with a radial spine at each angle. From each facet of the basal ring a strut of varying length rises to support an apical bar, either directly or by joining another to become a single auxiliary lateral rod. A complex apica structure with six openings of varying size and shape results. Basal accessory spines are present.

\section{Genus DISTEPHANUS Stöhr, 1880}

Distephanus boliviensis (Frenguelli) (Plate 2, Figures 8-12)

Dictyocha boliviensis Frenguelli, 1940, fide Loeblich et al., 1968, Geol. Soc. Am. Mem. 106, p. 83, pl. 9, fig. 3.

Distephanus boliviensis (Frenguelli) Bukry and Foster, 1973, Initial Reports of the Deep Sea Drilling Project, v. 16, p. 827, pl. 4, fig. 1-3.

Remarks: Distephanus boliviensis has a large six- or seven-sided basal ring. Radial spines of equal length punctuate each angle of the body outline. Lateral rods from midpoints of each facet of the basal ring support an open apical ring. Proximal pikes, one per facet, usually occur on the basal ring. Bukry and Foster (1973) find characteristic forms most prominent in upper Pliocene samples from DSDP Site 157, but note smaller forms with one pair of opposing radial spines longer than the others (resembling Distephanus speculum) to occur in the lower Pliocene and upper upper Miocene.

\section{Distephanus crux (Ehrenberg) \\ (Plate 3, Figures 1-3)}

Dictyocha crux Ehrenberg, 1940, fide Loeblich et al., 1968, p. 85 , pl. 8, fig. 29-32.

Distephanus crux (Ehrenberg) Haeckel, Mandra, 1968, Calif. Acad. Sci., Proc., ser. 4 , v. 36 , no. 9 , p. 254 , fig. $59,64,81$.

Remarks: Distephanus crux has a square or rhombic basal ring with four radial spines, one at each apex. One pair of opposite spines is 
always longer than the other pair. From the middle of each side, which may be sinuous or rounded, a lateral rod rises to support an apical ring which is frequently square in shape. Basal accessory spines may or may not be present.

\section{Distephanus longispinus (Schulz)}

Distephanus crux (Ehrenberg) Haeckel forma longispina Schulz, 1928, fide Loeblich et al., 1968, Geol. Soc. Am. Mem. 106, p. 120 , pl. 24 , fig. 29.

Distephanus longispinus (Schulz) Bukry and Foster, 1973, Initial Reports of the Deep Sea Drilling Project, v. 16, p. 828, pl. 4 , fig. $7,8$.

Remarks: Distephanus longispinus has a somewhat elliptic, foursided body ring with an extremely long radial spine at each end of the long axis and two short spines opposite one another punctuating the shorter axis. Four lateral rods, one from the center of each basal side, rise to support a relatively large, square, apical ring.

\section{Distephanus minutus (Bachmann) \\ (Plate 3, Figures 4, 6)}

Dictyocha speculum Ehrenberg forma minuta Bachmann in Ichikawa et al., 1967, fide Loeblich et al., 1968, Geol. Soc. Am. Mem. 106, p. 115 , pl. 52 , fig. $25-39$.

Distephanus minutus (Bachmann) Bukry and Foster, 1973, Initial Reports of the Deep Sea Drilling Project, v. 16, p. 828, pl. 4, fig. 10,11 .

Remarks: Distephanus minutus has a hexagonal basal ring with six radial spines, one at each apex. Two opposed spines are always longer than the other four. An exceptionally large, hexagonal apical ring distinguishes this species from Distephanus speculum. Because of the size of the apical ring, the six lateral rods connecting it to the facets of the body ring are frequently hard to see in apical view.

\section{Distephanus octonarius (Ehrenberg)} (Plate 3, Figure 9)

Dictyocha octonaria Ehrenberg, 1844, fide Loeblich et al., 1968, Geol. Soc. Am. Mem. 106, p. 107, pl. 19, fig. 13.

Distephanus octonarius (Ehrenberg) Haeckel, 1887, Rept. Sci. Results Voyage of H.M.S. Challenger during the years 1873-1876, v. 18, p. 1566.

Remarks: An octagonal basal ring with eight radial spines, one at each apex, characterize this species. An apical ring of moderate size, distinguishes Distephanus octonarius from $D$. octogonus, which though sometimes eight-sided, may or may not have an apical structure. When present, the apical ring of $D$. octogonus is extremely large.

\section{Distephanus polyactis (Ehrenberg)}

Dictyocha polyactis Ehrenberg, 1839, fide Loeblich et al., 1968, Geol. Soc. Am. Mem. 106, p. 109, pl. 19, fig. 9.

Distephanus polyactis (Ehrenberg) Deflandre, 1932, Soc. Bot. France, Bull., v. 79, p. 501, fig. 40 .

Distephanus polyactis (Ehrenberg) Ciesielski, 1975, Initial Reports of the Deep Sea Drilling Project, v. 28, pl. 10, fig. 12-17.

Remarks: One specimen resembling the forms chosen by Ciesielski to represent Distephamus polyactis was recorded from Site 324.

\section{Distephnaus quinquangellus Bukry and Foster (Plate 3, Figures 5, 8)}

Distephanus speculum (Ehrenberg) Haeckel var. pentagonus Lemmermann, 1901, fide Loeblich et al., 1968, Geol. Soc. Am. Mem. 106, p. 122 , pl. 25 , fig. 5 .

Distephanus quinquangellus Bukry and Foster, 1973, Initial Reports of the Deep Sea Drilling Project, v. 16, p. 828 , pl. 5, fig. 4.

Remarks: Distephanus quinquangellus has a symmetric five-sided basal ring with five radial spines, one at each apex. A lateral rod rising from each side of the body ring supports a symmetric pentagonal apical ring. Usually five small, proximally directed pikes occur on the basal ring.

\section{Distephanus septenarius (Ehrenberg)}

(Plate 3, Figures 7, 10, 11)

Dictyocha septenaria Ehrenberg, 1844, fide Loeblich et al., 1968, Geol. Soc. Am. Mem. 106, p. 113, pl. 21, fig. 18.
Distephanus septenarius (Ehrenberg) Frenguelli, 1938, La Plata Univ. Nac., Inst. Mus. La Plata, Notas, v. 3, Zoc!. no. 11, p. 121, fig. 1-3.

Distephamus septenarius (Ehrenberg), Perch-Nielsen, 1975, Initial Reports of the Deep Sea Drilling Project, v. 29, p. 688, pl. 7, fig. $21,22$.

Remarks: This species has a large seven-sided basal ring with a radial spine at each apex. Basal accessory pikes are usually present between seven lateral rods which support an apical ring.

\section{Distephanus speculum (Ehrenberg)}

(Plate 3, Figure 12; Plate 4, Figures 1, 3)

Dictyocha speculum Ehrenberg, 1839, fide Loeblich et al., 1968, Geol. Soc. Am. Mem. 106, p. 114, pl. 24, fig. 1-10.

Distephanus speculum (Ehrenberg) Haeckel, 1887, Rept. Sci. Results Voyage of H.M.S. Challenger during the years $1873-1876$, v. 18 , p. 1565 .

Remarks: Distephanus speculum has a hexagonal basal ring, two opposing radial spines that are longer than the other four, and an apical ring of moderate proportions. Forms of $D$. speculum with six radial spines of approximately equal length have been tabulated as $D$. speculum s. s. (Plate 4, Figures 2, 5).

\section{Distephanus speculum binoculus (Ehrenberg)}

Dictyocha binoculus Ehrenberg, 1844, fide Loeblich et al., 1968, Geol. Soc. Am. Mem. 106, p. 83, pl. 8, fig. 8.

Distephanus speculum binoculus (Ehrenberg) Bukry, 1975, Initial Reports of the Deep Sea Drilling Project, v. 29, p. 855.

Remarks: An apical ring divided into two relatively equal windows distinguishes Distephanus speculum binoculus from Distephanus speculum. Both species have two opposing radial spines that are longer than the other four.

\section{Distephanus speculum var. pseudocrux Schulz} (Plate 4, Figure 6)

Distephanus speculum (Ehrenberg) Haeckel forma pseudocrux Schulz, 1928, fide Loeblich et al., 1968, Geol. Soc. Am. Mem. 106, p. 122, pl. 25, fig. 14-16.

Distephanus speculum var. pseudocrux (Schulz) Tsumura, 1963, Yokohama Municipal Univ., J. C-45, no. 146, expl. pl. 12, fig. $2,3$.

Remarks: Ling (1972, p. 218, pl. 27, Fig. 5-7) shows this form with five- or six-sided basal rings. It is distinguished by the complex structure of lateral rods which supports a small apical window. From each facet of the basal ring a strut of varying length rises either directly to the window or joins another to become a single lateral support. Lateral windows are thus of various sizes and shapes.

\section{Genus LYRAMULA Hanna, 1928}

\section{Lyramula tenuipertica var. laevis Tsumura} (Plate 4, Figures 4, 7)

Lyramula tenuipertica Kokubo and Tsumura in Tsumura, var. laevis Tsumura, 1963, fide Loeeblich et al., 1968, Geol. Soc. Am. Mem. 106 , p. 126 , pl. 26 , fig. 8 a, 8 b.

Remarks: The outline of this form is essentially V-shaped with a very small spine at the apex. It has long, slender, slightly undulate bars, the surface of which are quite smooth.

\section{Genus MESOCENA Ehrenberg, 1843}

\section{Mesocena apiculata (Schulz)}

(Plate 4, Figures 10, 12)

Mesocena oamaruensis Schulz var, apiculata Schulz, 1928, fide Loeblich et al., 1968, Geol. Soc. Am. Mem. 106, p. 129, pl. 28, fig. 6.

Mesocena apiculata (Schulz) Hanna, 1931, Mining in Calif., p. 198, pl. D, fig. 3 .

Remarks: Mesocena apiculata is triangular in outline, varying in form from equilateral to isosceles, with sides either straight or somewhat bowed. The specimens found at Sites 322 and 323 had septae at the apices. 


\section{Mesocena diodon Ehrenberg}

Mesocena diodon Ehrenberg, 1844, fide Loeblich et al., 1968, Geol. Soc. Am. Mem. 106, p. 128, pl. 27, fig. 4.

Remarks: This species is elliptical in outline and has a distal spine at opposing ends of the major axis of the body ring.

\section{Mesocena elliptica (Ehrenberg)}

Dictyocha (Mesocena) elliptica Ehrenberg, 1840, fide Loeblich et al., 1968, Geol. Soc. Am. Mem. 106, p. 89, pl. 8, fig. 25-26.

Mesocena elliptica (Ehrenberg) Ehrenberg, 1844, Ber. Verh. K. Preuss.

Akad. Wiss. Berlin, p. 71, 84.

Remarks: The body ring of Mesocena elliptica varies in outline from rhomoid to circular. Four distally directed spines at the apices of rhomboid forms or symmetrically $90^{\circ}$ apart on circular forms distinguish the species. The surface of the body ring may be smooth or ornamented by irregularly spaced pikes.

\section{Mesocena elliptica var. triangula Bachmann and Ichikawa} (Plate 4, Figure 11)

Mesocena elliptica (Ehrenberg) Ehrenberg var, triangula Bachmann and Ichikawa, 1962, fide Loeblich et al., 1968, Geol. Soc. Am. Mem. 106, p. 128 , pl. 27, fig. $12,13$.

Remarks: This species has an elliptical body ring but is distinguished by having only three radial spines, two opposed at ends of the long axis and one punctuating one end of the short axis.

\section{Genus PARADICTYOCHA Frenguelli, 1940}

\section{Paradictyocha apiculata (Lemmermann)}

Mesocena circulus (Ehrenberg) Ehrenberg var. apiculata Lemmermann, 1901, fide Loeblich et al., 1968, Geol. Soc. Am. Mem. 106, p. 127 , pl. 27 , fig. $3 a, 3 b$.

Paradictyocha apiculata (Lemmermann) Frenguelli, 1940, Rev. Mus. La Plata, ser. 2, v. 2, Paleontol. no. 7, p. 52, pl. 4, fig. 4.

Remarks: For synonymy and discussion of the species see

Dumitrica (1973). One specimen of this form was found at Site 322.

\section{Paradictyocha circulus (Ehrenberg)}

(Plate 4, Figures 8, 9)

Dictyocha (Mesocena) circulus Ehrenberg, 1840, fide Loeblich et al., 1968, Geol. Soc. Am. Mem. 106, p. 84, pl. 8, fig. 20

Paradictyocha circulus (Ehrenberg) Dumitrica, 1973, Initial Reports of the Deep Sea Drilling Project, v. 21, p. 853, pl. 9, fig. 7-10.

Remarks: Paradictyocha circulus is a simple circular or polygonal ring with 18-25 short, radial spines lying in the plane of the basal ring.

The surface of the body has many scattered, minute thorns.

\section{Paradictyocha dumitricae Perch-Nielsen}

Paradictyocha dumitricae Perch-Nielsen, 1975, Initial Reports of the Deep Sea Drilling Project, v. 29, p. 689, pl. 11, fig. 1, 5-8.

Remarks: This species is polygonal in outline and has short, radial spines of equal length at each angle of its body ring. Specimens with 11-21 such spines have been reported. Lateral spines are absent in this form.

\section{ACKNOWLEDGMENTS}

We wish to thank the scientific party onboard Glomar Challenger Leg 35, especially F. Rögl, H.J. Schrader, and F.M. Weaver for their support. Most of the samples studied were provided by F.M. Weaver. P. Ciesielski made available his unpublished silicoflagellate zonation of DSDP Leg 28. We benefited from our discussions with L.H. Burckle. This paper was reviewed by D.A. Johnson and G.P. Lohmann. This is Woods Hole Oceanographic Institution Contribution 3565.

\section{REFERENCES}

Bachmann, A., 1967. Part II. Silicoflagellidae im Iida Diatomit. In Ichikawa, W. et al., Fossil silicoflagellates and their associated uncertain forms in Iida Diatomite, Noto Peninsula: Kenazawa Univ., Sci. Rept., v. 12, p. 149-172. Bukry, D., 1973. Coccolith and silicoflagellate stratigraphy, Deep Sea Drilling Project Leg 18, eastern North Pacific. In Kulm, L.D., von Huene, R., et al., Initial Reports of the Deep Sea Drilling Project, Volume 18: Washington (U.S. Government Printing Office), p. 817-831.

1975. Silicoflagellate and coccolith stratigraphy, Deep Sea Drilling Project, Leg 29. In Kennett, J.P., Houtz, R.E., et al., Initial Reports of the Deep Sea Drilling Project, Volume 29: Washington (U.S. Government Printing Office), p. 845-871.

Bukry, D. and Foster, J.H., 1973. Silicoflagellate and diatom stratigraphy, Leg 16, Deep Sea Drilling Project. In van Andel, T.H., Heath, G.R., et al., Initial Reports of the Deep Sea Drilling Project, Volume 16: Washington (U.S. Government Printing Office), p. 815-871.

Ciesielski, P.F., 1975. Biostratigraphy and paleoecology of Neogene and Oligocene silicoflagellates from cores recovered during Antarctic Leg 28, Deep Sea Drilling Project, Volume 28: Washington (U.S. Government Printing Office), p. 625-692.

Dumitrica, P., 1973. Paleocene, late Oligocene and postOligocene silicoflagellates in southwestern Pacific. sediments cored on Deep Sea Drilling Project Leg 21. In Burns, R.E., Andrews, J.E., et al., Initial Reports of the Deep Sea Drilling Project, Volume 21: Washington (U.S. Government Printing Office), p. 837-883.

Ehrenberg, C.G., 1837. Eine briefliche Nachricht des Hrn. Agassiz in Neuchatel über den ebenfalls aus. mikroskopischen Kiesel-Organismen gebildeten Polirschiefer von Oran in Afrika: Berlin, Ber. Verh. K. Preuss. Akad. Wiss., p. 59-61.

1943. Verbeitung und Einfluss des mikroskopischen Lebens in Süd- und Nord-Amerka: Akad. Wiss. Berlin, Abh., 1841, p. 291-446.

Frenguelli, J., 1940. Consideraciones sobre los sílicoflagelados fósiles: Rev. Mus. la Plata, ser. 2, v. 2, Paleontol. no. 7, p. 37-112.

Haeckel, E.H.P.A., 1887. Report on the radiolaria collected by H.M.S. Challenger during the years 1873-1876: Rept. Sci. Results Voyage H.M.S. Challenger during the years 18731873 , v. 18 , p. $1-1803$.

Hanna, G.D., 1928. Silicoflagellata from the Cretaceous of California: J. Paleontol., v. 1, p. 259-263.

Ling, H.Y., 1972. Upper Cretaceous and Cenozoic silicoflagellates and ebridians: Bull. Am. Paleontol., v. 62, p. 135-223.

1973. Silicoflagellates and ebridians from Leg 19: In Creager, J.S., Scholl, D.W., et al., Intial Reports of the Deep Sea Drilling Project, Volume 19: Washington (U.S. Government Printing Office), p. 751-775.

Loeblich, A.R., III, Loeblich, L.A., Tappan, H., and Loeblich, A.R., Jr., 1968. Annotated index of fossil and recent silicoflagellates and ebridians with descriptions and illustrations of validly proposed taxa: Geol. Soc. Am. Mem. 106 , p. 1-319.

Mandra, Y.T., 1968. Silicoflagellates from the Cretaceous, Eocene and Miocene of California, U.S.A.: Calif. Acad. Sci. Proc., v. 36, p. 231-277.

Perch-Nielsen, K., 1975. Late Cretaceous to Pleistocene silicoflagellates from the southern Southwest Pacific, Deep Sea Drilling Project, Leg 29: In Kennett, J.P., Houtz, R.E., et al., Initial Reports of the Deep Sea Drilling Project, Volume 29: Washington (U.S. Government Printing Office), p. 677-721.

Stöhr, Emil, 1880. Die Radiolarienfauna der Tripoli von Grotte, Provinz Girgenti in Sicilien: Paleontographica, v. 26 , p. $69-124$. 


\section{PLATE 1}

Silicoflagellates from DSDP Leg 35

(Figures 1-9, 11, and 12 magnified $500 \times$, Figure 10 magnified $625 \times$ )

Figures 1-3 Cannopilus ernestinae Bachmann.

1-3. Sample 323-3-2, 130-132 cm.

2, 3. High and low focus on single specimen.

Figure 4 Corbisema bimucronata Deflandre.

Sample 323-3, CC.

Figure 5 Corbisema triacantha (Ehrenberg). Sample 323-6, CC.

Figure 6 Corbisema hastata hastata (Lemmermann). Sample 323-3, CC.

Figures 7-9 Dictycha aspera (Lemmermann).

7. Sample 34-1-3, 82-84 cm.

8. Sample 323-2-1, 65-67 cm.

9. Sample $322-1-2,114-116 \mathrm{~cm}$.

Figures 10-12 Cannopilus binoculus (Ehrenberg) Lemmermann.

10. Sample 325-3-4, $45-47 \mathrm{~cm}$.

11. Sample $324-1-3,30-32 \mathrm{~cm}$.

12. Sample $322-1-3,90-92 \mathrm{~cm}$. 
PLATE 1
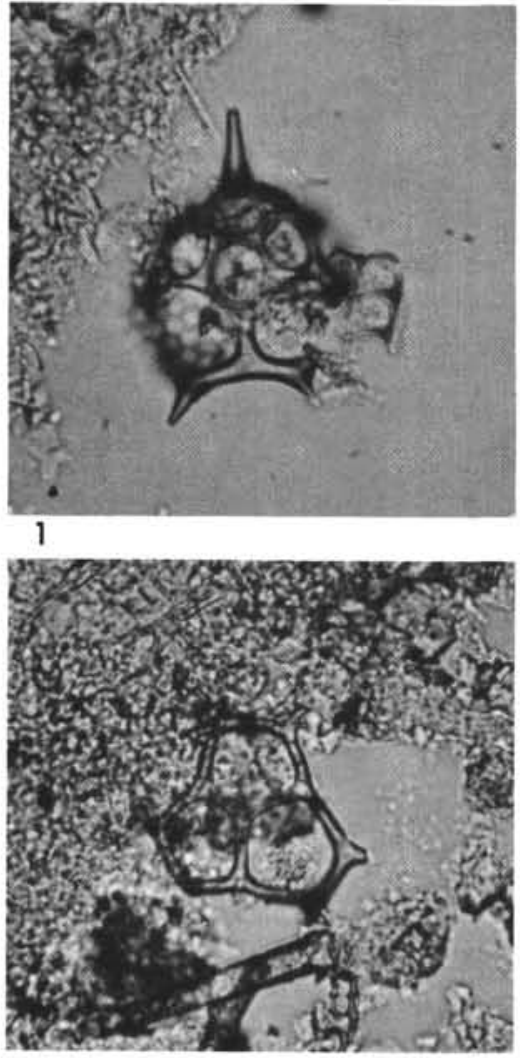

4

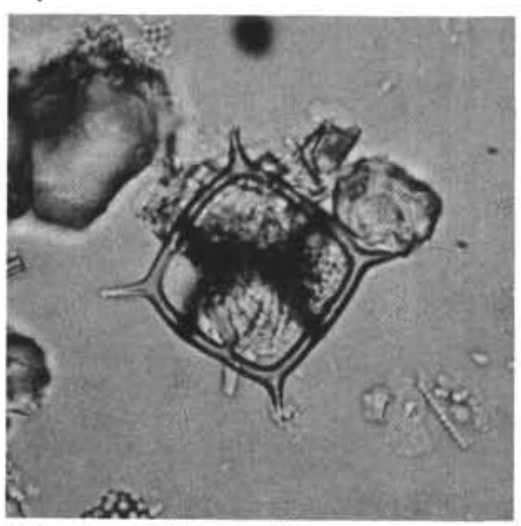

7

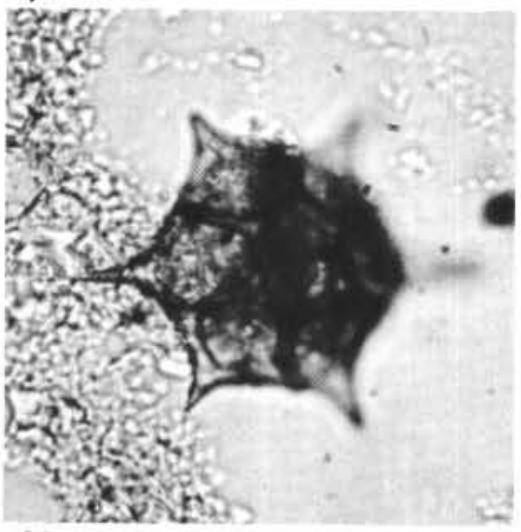

10

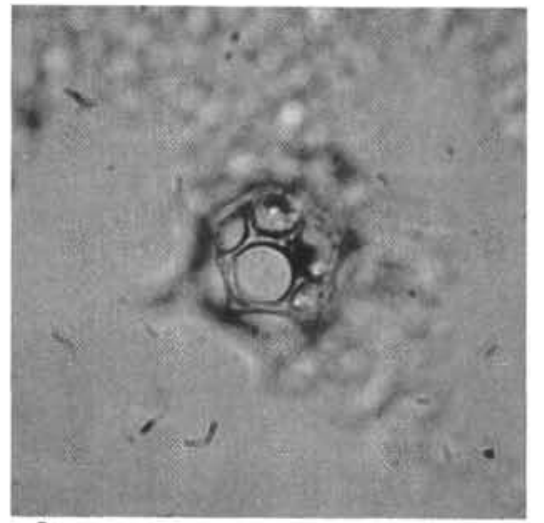

\section{2}

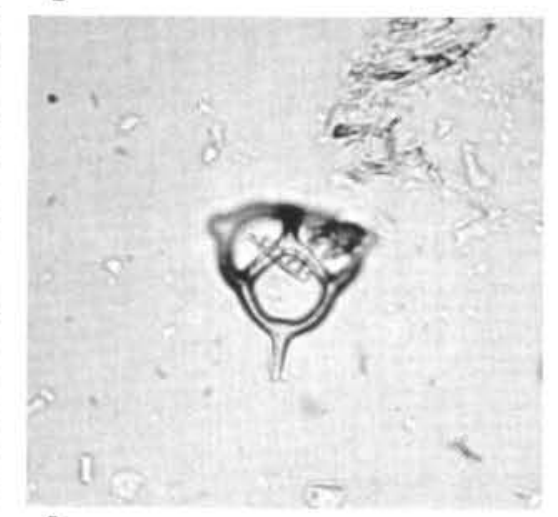

5

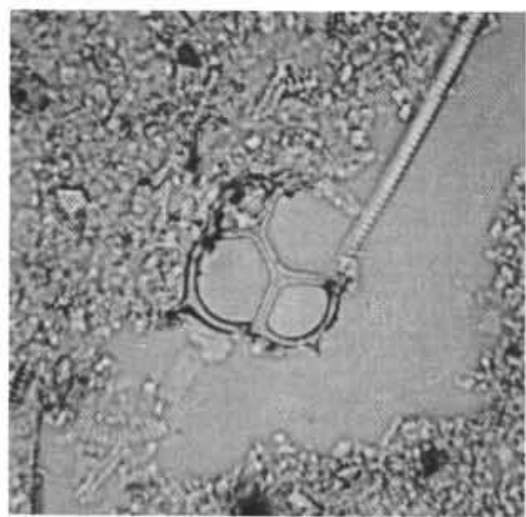

8

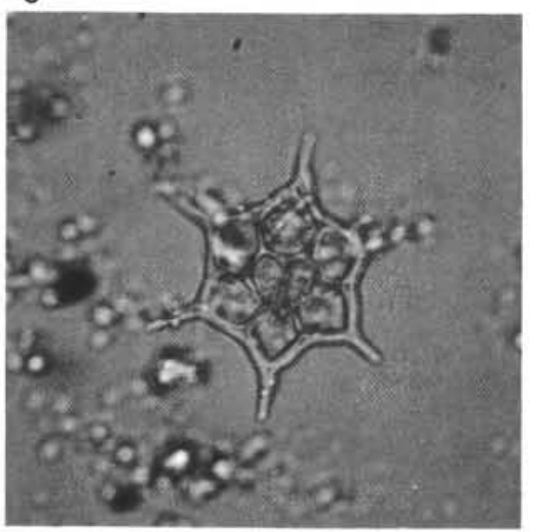

11

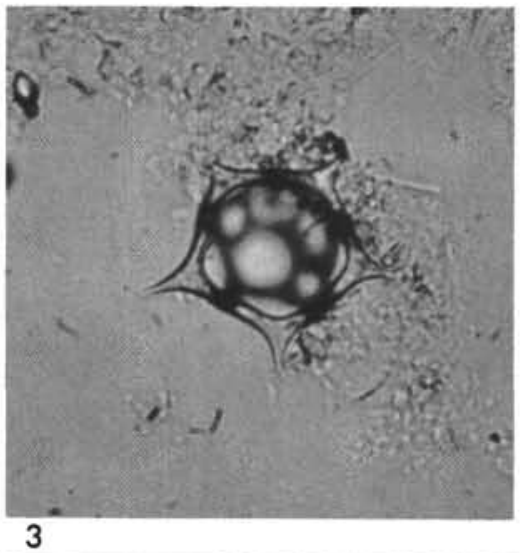

(1)

90 a and

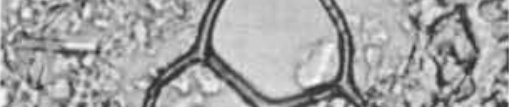

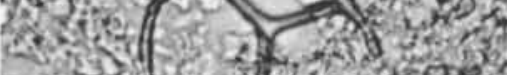

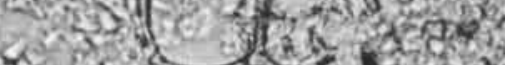

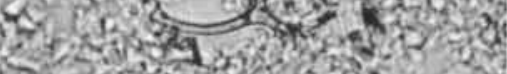

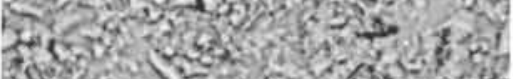

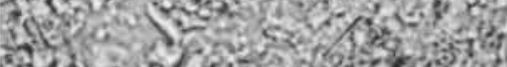

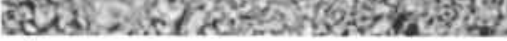
6

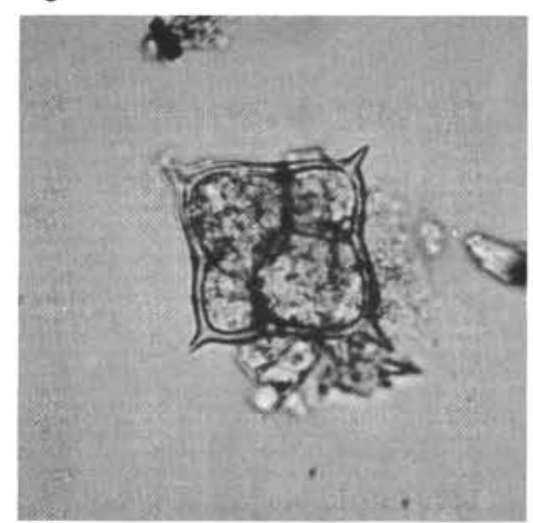

9

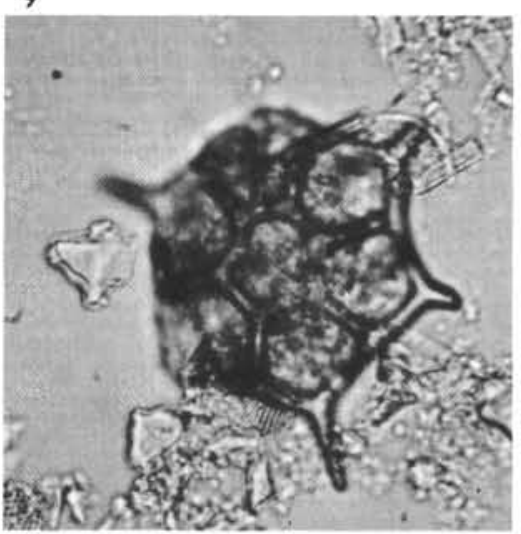

12 


\section{PLATE 2}

Silicoflagellates from DSDP Leg 35

(Magnification $500 \times$ )

Figures 1-3 Dictyocha epiodon Ehrenberg. Sample 322-1-1, 78$80 \mathrm{~cm}$.

Figure 4 Dictyocha fibula perlaevis (Frenguelli). Sample $323-2-1,65-67 \mathrm{~cm}$.

Figure 5 Dictyocha fibula cf. rotundata Schulz. Sample 322-1-1, 78-80 cm.

Figure 6 Dictyocha aspera (Lemmermann). Sample 323-3, CC.

Figure 7 Dictyocha pseudofibula (Schulz). Sample 322-1-2, 114-116 cm.

Figures 8-12 Distephanus boliviensis (Frenguelli).

8. Sample $324-1-1,143-145 \mathrm{~cm}$.

9,12 . Sample $325-3$, CC. High and low focus on single specimen.

10. Sample $322-2-2,97-99 \mathrm{~cm}$.

11. Sample 323-2-1, 65-67 cm. 
PLATE 2
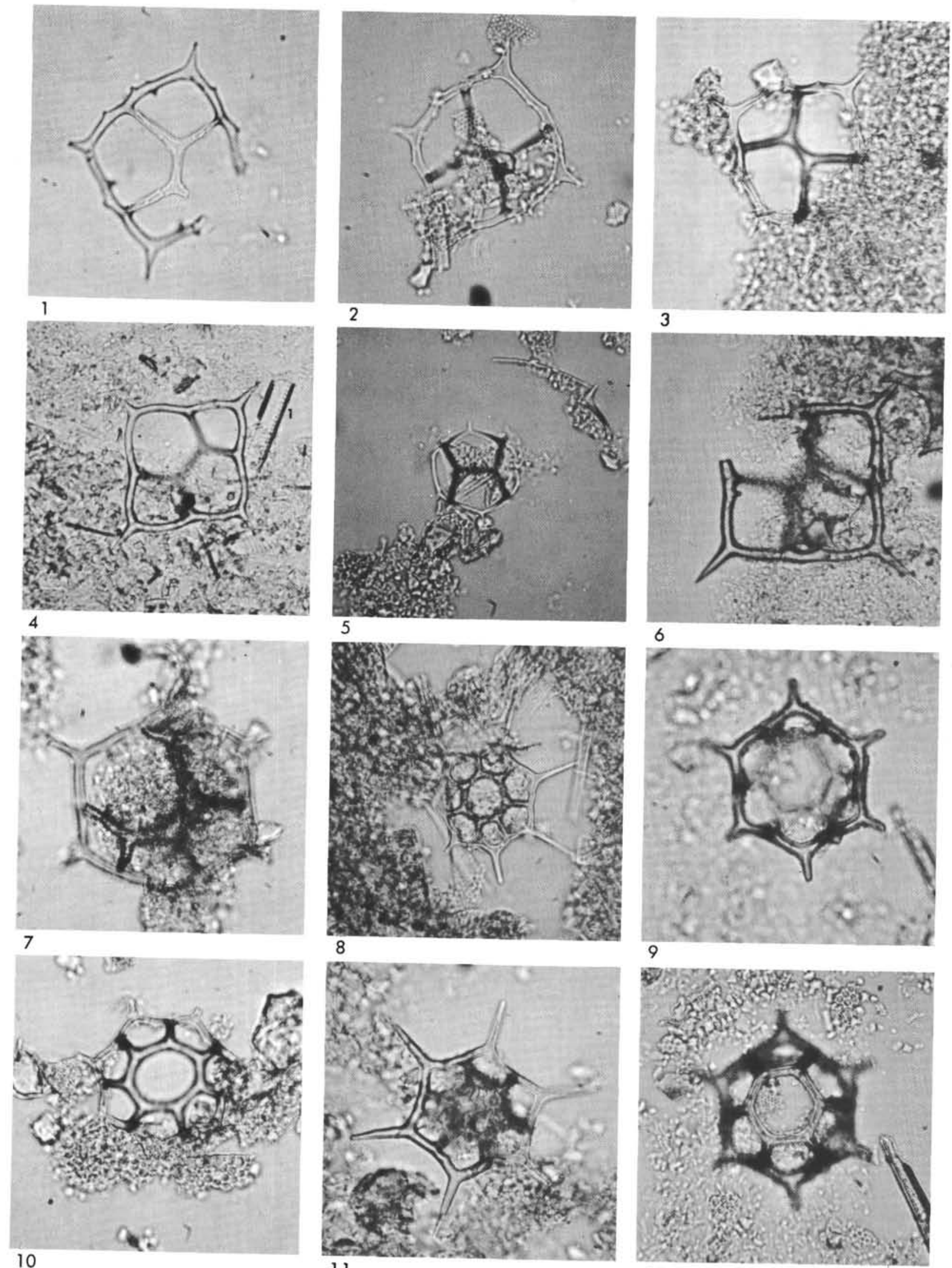


\section{PLATE 3}

Silicoflagellates from DSDP Leg 35

(Figures 1-7 and 9-12 magnified $500 \times$ Figure 8, magnified $625 \times$ )

Figures 1-3 Distephanus crux (Ehrenberg).

1. Sample 323-6, CC.

2. Sample 323-3, CC.

3. Sample 323-7-1, Green.

Figures 4, 6 Distephanus minutus (Bachmann).

4. Sample 325-3-4, $45-47 \mathrm{~cm}$.

6. Sample $324-1-1,143-145 \mathrm{~cm}$.

Figures 5, 8 Distephanus quinquangellus Bukry and Foster.

5. Sample 324-1-6, 17-19 cm.

8. Sample $324-1-5,86-88 \mathrm{~cm}$.

Figures 7, 10, 11 Distephanus septenarius (Ehrenberg).

7. Sample 325-3-2, 105-107 cm.

10, 11. Sample $322-2-2,97-99 \mathrm{~cm}$. High and low focus on single specimen.

Figure 9 Distephanus octonarius (Ehrenberg).

Sample 322-2-2, 97-99 cm.

Figure 12 Distephanus speculum (Ehrenberg).

Sample 325-3, CC 
PLATE 3

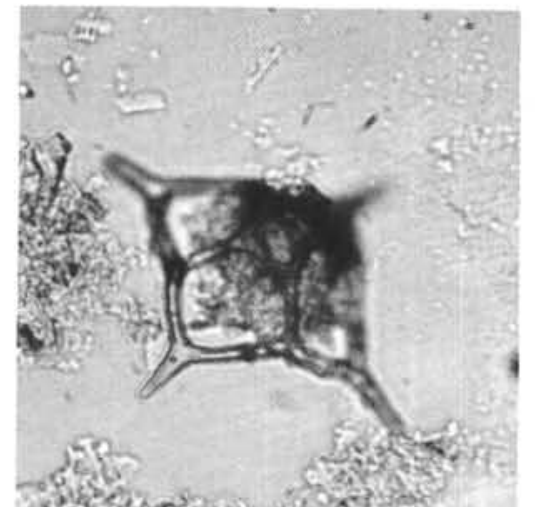

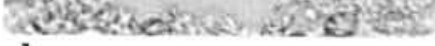

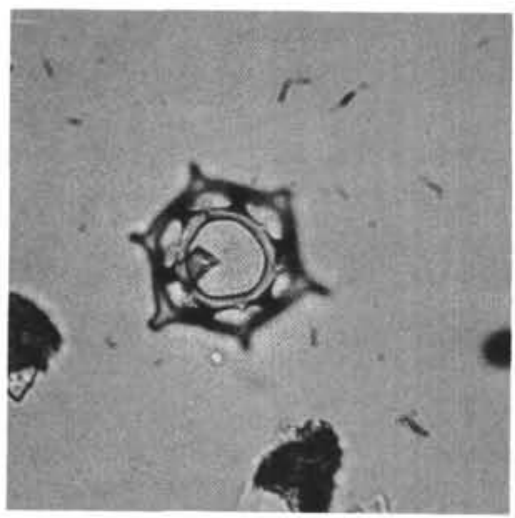

4
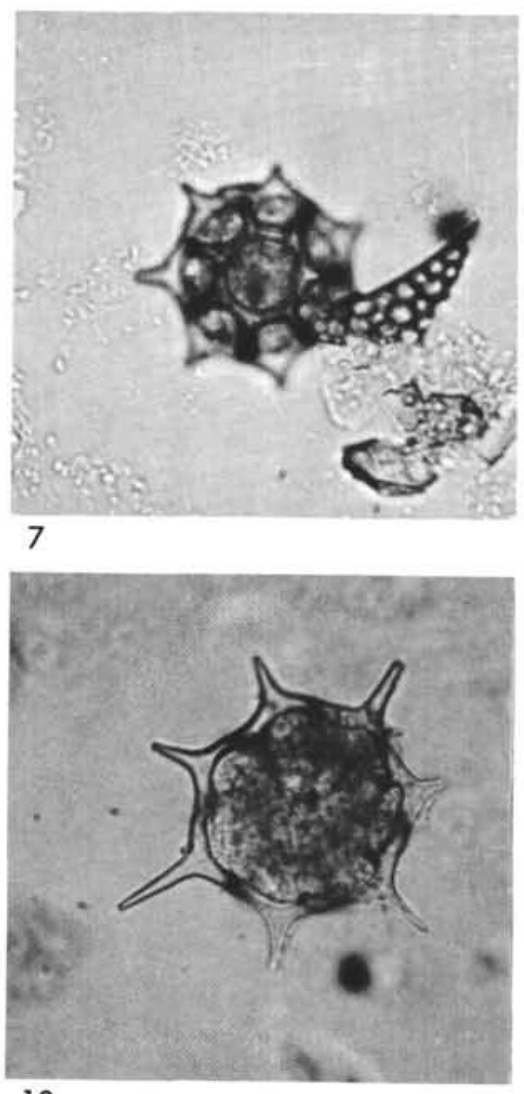

10

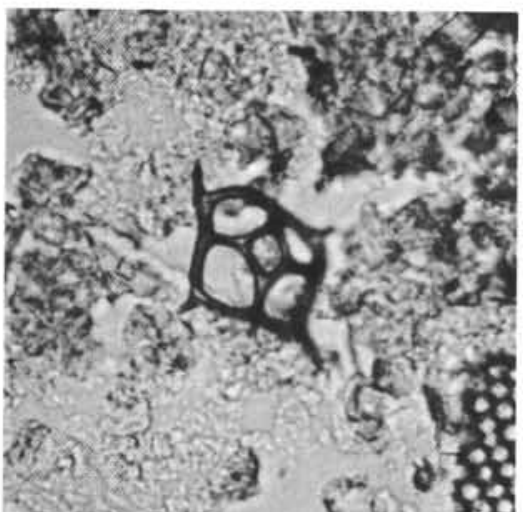

2

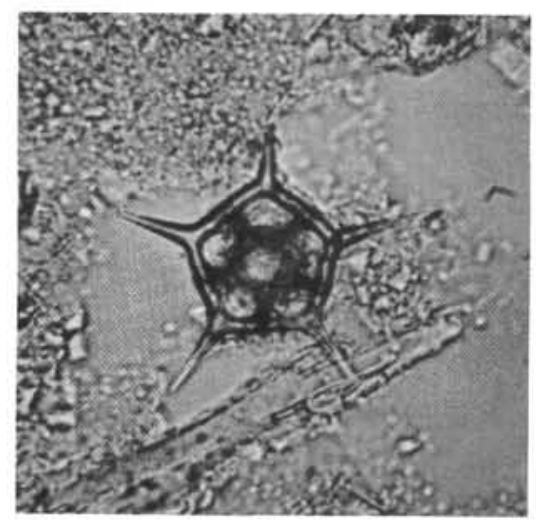

5

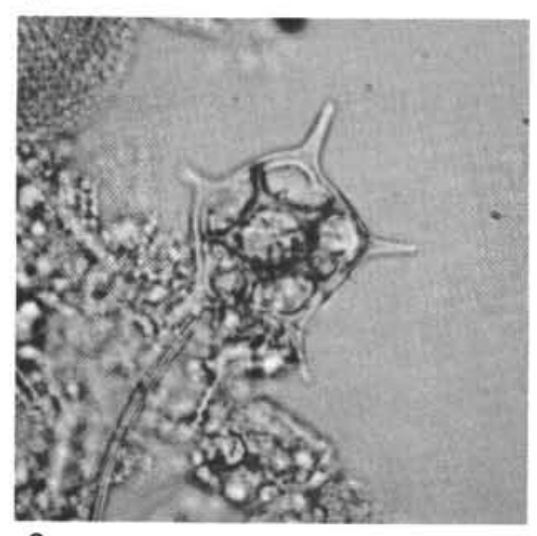

8

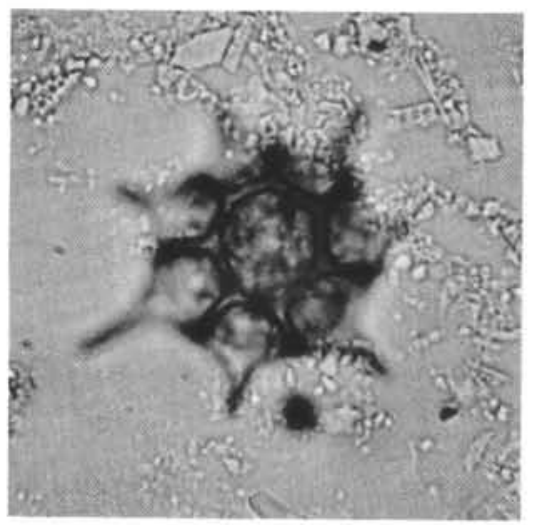

11

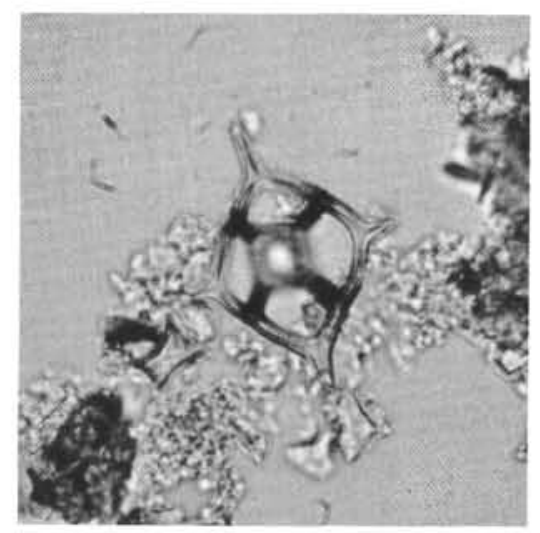

3

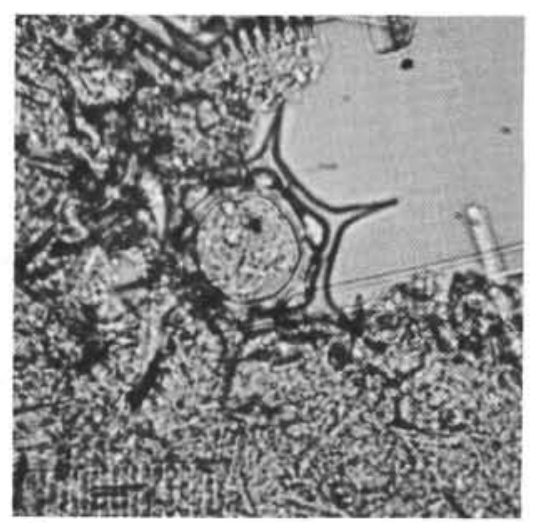

6

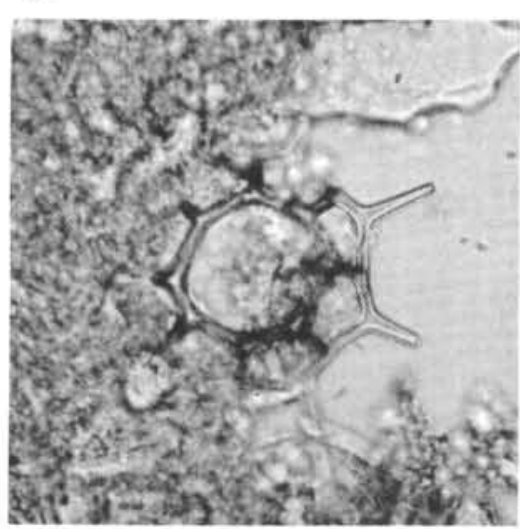

9

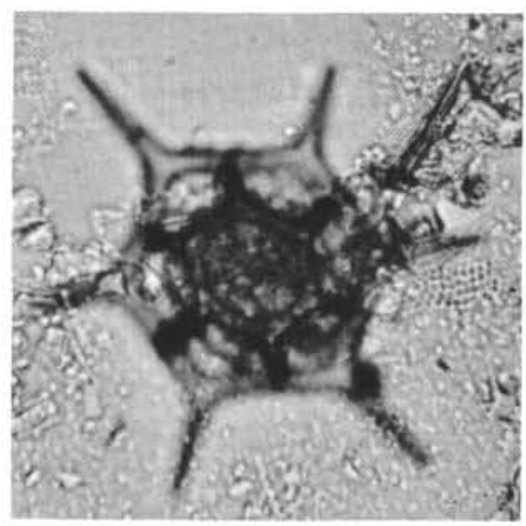

12 


\section{PLATE 4}

Silicoflagellates from DSDP Leg 35 (Magnification $500 \times$ )

Figures 1, 3 Distephanus speculum (Ehrenberg).

1. Sample 323-2-1, 65-67 cm.

3. Sample 322-2-2, $97-99 \mathrm{~cm}$.

Figures 2, $5 \quad$ Distephanus speculum s.s.

2. Sample 324-1-2, $53-55 \mathrm{~cm}$.

5. Sample $324-1-1,143-145 \mathrm{~cm}$.

Figures 4,7 Lyramula tenuipertica var. laevis Tasmura. Sample 322-2-2, 97-99 cm.

Figure 6 Distephanus speculum var. pseudocrux Schulz. Sample 322-1-2, 114-116 cm.

Figures 8,9 Paradictyocha circulus (Ehrenberg).

8. Sample 322-2-2, $97-99 \mathrm{~cm}$.

9. Sample $322-1-3,19-21 \mathrm{~cm}$.

Figures 10, 12 Mesocena apiculata (Schulz).

10. Sample 323-3, CC.

12. Sample 323-3-2, $80-82 \mathrm{~cm}$.

Figure $11 \quad$ Mesocena elliptica var. triangula Bachmann and Ichikawa.

Sample 322-1-2, 114-116 cm. 
PLATE 4
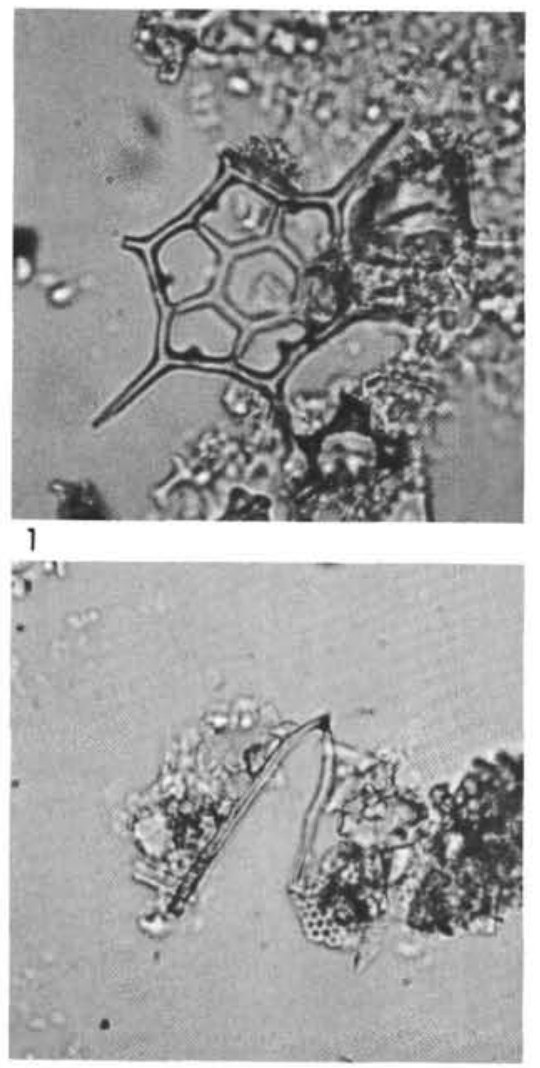

4

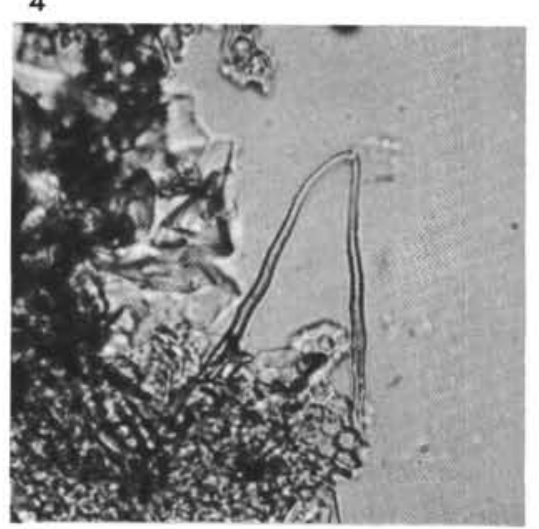

7

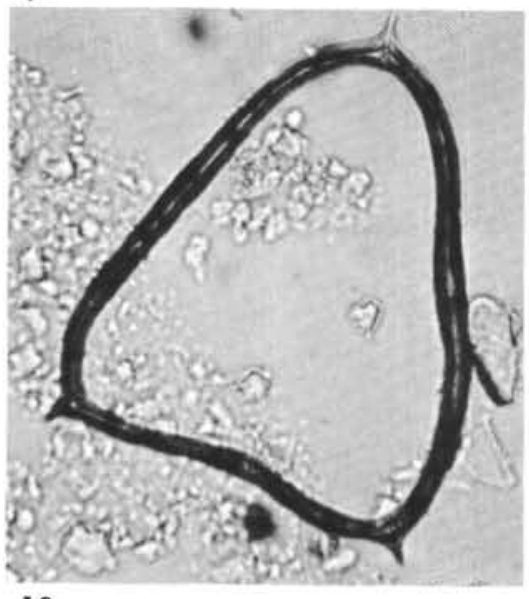

10
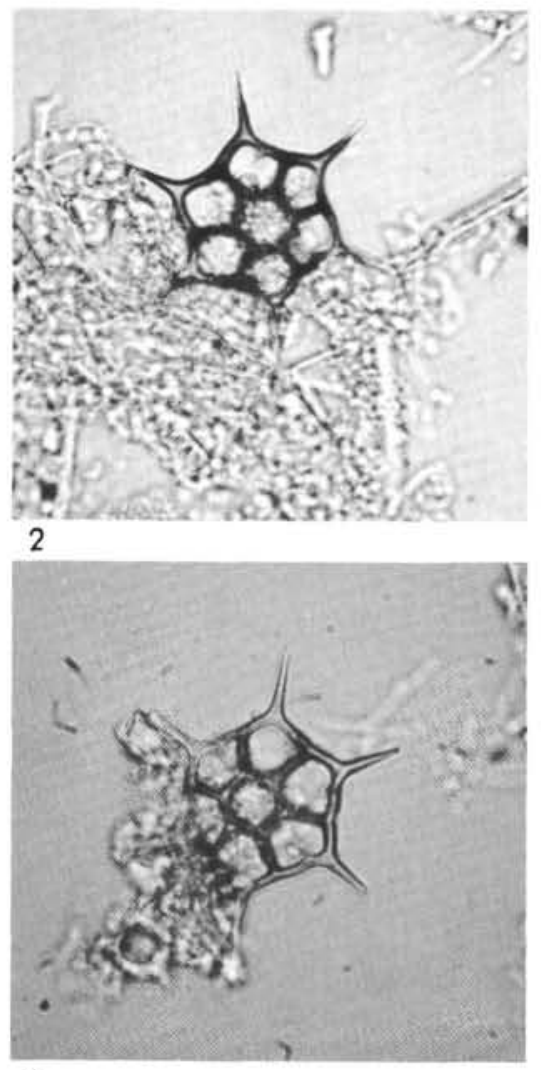

5

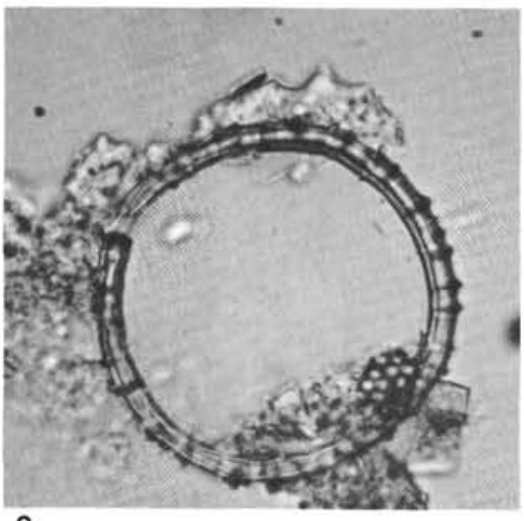

8

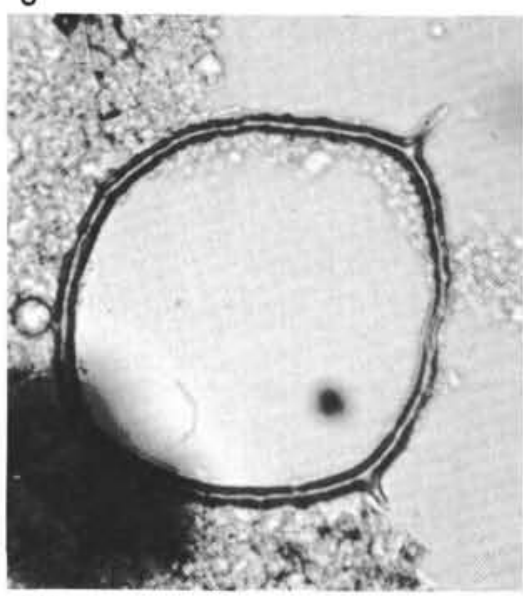

11

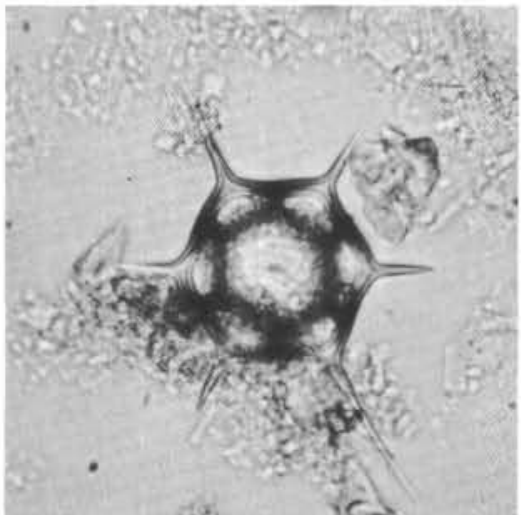

3

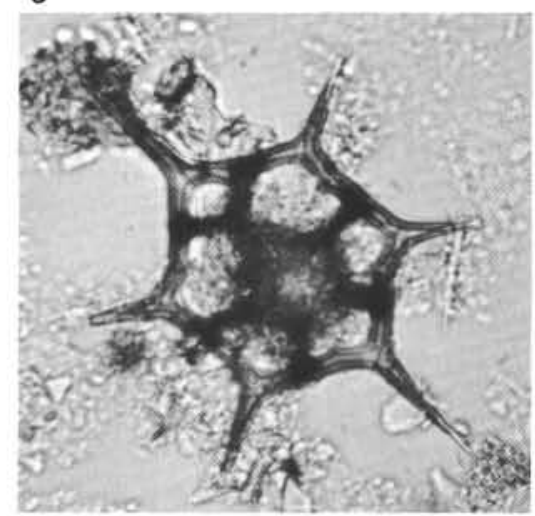

6

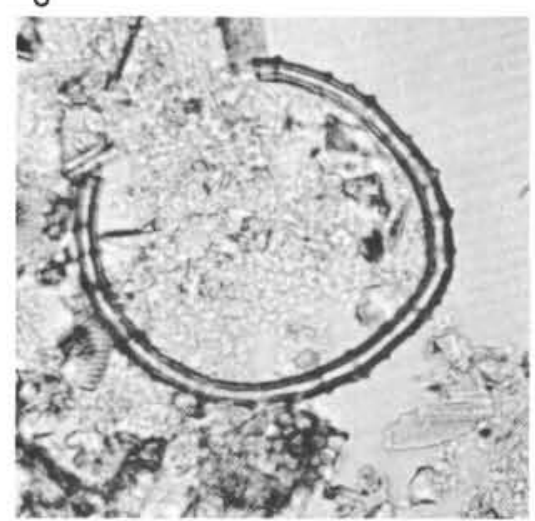

9

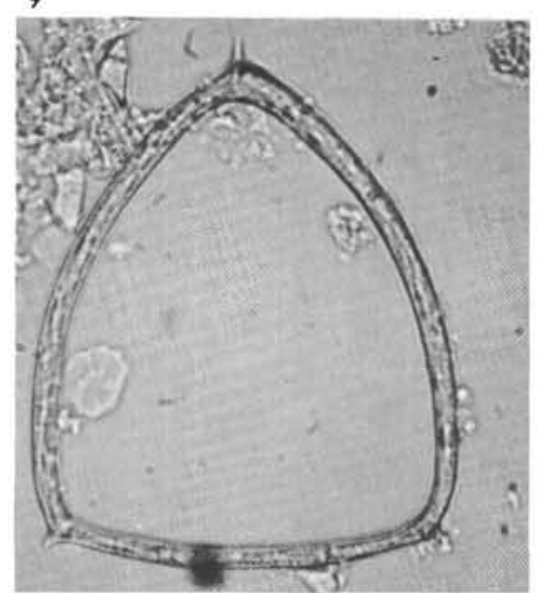

12 